\title{
JÁNOS KÁDÁR AS AN ECONOMIC REFORMIST AND GUSTÁV Husák AS AN ANTIREFormist
}

\section{Zsolt Horbulák ${ }^{1}$}

\begin{abstract}
This paper deals with both political and economic history. The main task was to try to compare the attitude of Gustáv Husák and János Kádár about economic reforms in their own countries. The comparison was based on their lives, interests and personalities. Historical evaluation and biographical material was also used. Taking into account that the political circumstances were very similar, the root of the differences between the acts of these politicians had to be the result of individual factors. However, it cannot be denied that the difference between the development of Czechoslovakia and Hungary also played a significant role.
\end{abstract}

KEY WORDS: Gustáv Husák, János Kádár, Czechoslovakia, Hungary, economic reforms

\section{INTRODUCTION}

The development of historical events is traditionally strongly influenced by the acts of persons in the highest positions in a country. History is not made by classes or social strata, but by people as individuals. This is even truer for the heads of states, for kings or presidents. Character, interests, childhood, education, health, family life and many other factors are equally present in the background of a ruler's every decision, such as the current economic and political situation of the state or international conditions. Based on our current knowledge, the living traces of Gustáv Husák and János Kádár have not yet been processed by historians. But the fact remains that when historians assess the history of the Czechoslovak Socialist Republic and the Hungarian People's Republic, or when they write the biography of these two politicians, they often present their actions in parallel. The historical facts are juxtaposed so as to compare their activities directly. Their career paths are very similar. They lived and worked at the same historical moment and in the same political circumstances. Their age was but one year from being the same. Their style of government and, in particular, their political legacy, however, is completely different. This is stated by historians as well as by the population of the countries where they took over the top position.

Socialism could be described by a few quite delimited definitions: monopoly

1 Assistant professor, Dept. of Social and Human Sciences, Faculty of Social and Economic Relations, University of Alexander Dubček in Trenčín, Študentská 2, 950 11, zsolt.horbulak@tnuni.sk 
of a political idea and a party, a regulated and centrally planned economy, common ownership of production factors, monopoly of mass information, antireligionism. Despite this fact, among communist countries there were visible differences. The divergence among the states, by and by, became considerable. The communist countries were also dictatorships, therefore the political and economic development depended considerably on the leader of the communist party. This so happened in Hungary and Czechoslovakia "under the rule" of János Kádár and Gustáv Husák. In this paper an attempt to analyse the economic policies of the above mentioned persons.

In this work a narrower issue is examined. Economic reforms in the Hungarian People's Republic and the Czechoslovak Socialist Republic have already been recorded by economic historians. ${ }^{2}$ Now the focus will be on what attitude about economic reforms Gustáv Husák and János Kádár had in their own countries.

\section{FAMILY ORIGIN AND CHILDHOOD YEARS}

The first thing that the two politicians had in common was their date of birth: Kádár was born only 228 days earlier than Husák. Perhaps the most significant feature in the lives of Gustáv Husák and János Kádár could be found already in their youth. Both of them had committed left-wing ties whilst attending secondary school. Considering their origin, other similar features may be found. They both grew up in broken families. Husák's mother died in his infancy, while his father fell in World War during his childhood, Gustáv was raised by his grandmother. Kádár did not know his father, because he was born out of wedlock. He grew up in great poverty.

An interesting fact is that there were overlaps in terms of their nationality. Gustáv Husák was clearly of Slovakian descent, but he was born in Dúbravka, attended secondary school and university in Bratislava, in a town on the Hungarian language border area. Husák lived in that era when knowledge of the Hungarian language was quite common. This is further intensified by the fact

2 Besides the literature listed on the paper about Hungary see more e. g. Nyers R. 1988. Útkeresés, reformok; Berend T. I. 1988. A magyar gazdasági reform útja. Budapest, Közgazdasági és Jogi Könyvkiadó; Földes Gy. 1995. Az eladósodás politikatörténete. 1957-1986, Maecenas; Mihályi P. 2013. A magyar gazdaság útja az adósságválságba. 1945-2013. Corvina, Budapest. In case of Czechoslovakia see e. g. Šulc, Z. 1998. Stručné dějiny reforem v Československu (České republice) 1945-1995. Doplněk, Brno; Jech, K. \& Kaplan, K. \& Váchová, J. red. 1996. K ekonomické reformě 1965-1968. USD; Londák, M. \& Sikora, S. \& Londáková, E. 2002. Predjarie. Politický, ekonomický a kultúrny vývoj na Slovensku v rokoch 1960-1967. Veda, Bratislava; Londák, M. 2007. Rok 1968 a ekonomická realita Slovenska. Prodama, Bratislava 
that, among the working class, the German language was used above all. János Kádár himself was of half-Slovak descent. This also shows in his original name, which was Csermanek. In fact, his wife, Mary Tamáska, was Slovak born. Her parents wrote their names in the form Tomáska, and Kádár's father was born in Topolčany (Huszár, 2001, p. 113). All this does not mean that they had an affinity for the other nation, but rather to national and social characteristics of the historical reference to Hungary, which had several similar examples. The two future leaders also changed their names. Kádár changed his family name, and Husák added a new first name. He was originally called Agustín.

Gustáv Husák’s biographers refer in several places, to Husák having a strong nationalist feeling atypical for communists and internationalists (Sikora, 2013, p. 46, 54). A memorial also shows that this had already been noticed in his childhood (Sikora, 2013, p. 42). Husák, in 1945, as one of the leading personalities of the Czechoslovak Communist Party and Minister of Home Affairs, played a leading role in conducting a Slovak-Hungarian population exchange (Šutaj, 2013, pp. 282-311).

The major differences between the two can be found in terms of their level of education. Both of them were seriously self-educated: besides the Marxist classics they read many other books. The difference is that, while Husák attended secondary high school, and later graduated from the Comenius University Faculty of Law, where he was already acquainted with many representatives of the cultural elite (Plevza, 1991, p. 16, 19), Kádár attended only a vocational training school. For this reason, there are also differences in terms of their reading matter. Kádár read many popular books on youth literature, but had problems with the Marxist classics. However, his passion for chess and the results he achieved in this sport, is well-known (Huszár, 2001, p. 22, 26).

Gustáv Husák and János Kádár were also commonly involved in the labour movement during their school years, and also in the resistance during World War II. Moreover, they also had traits in common during the time of Stalinism: based on trumped-up charges, both of them were arrested. Perhaps Husák suffered more because he was detained for nine years; Kádár sat in prison for just two years. His personality influenced another politician during his participation in the Rajk trial. ${ }^{3}$ His fate was even formed in the same way in how they came to power during the most critical period in their country. What became wholly different were their policies.

3 László Rajk, Minister of the Interior, was accused of being a Titoist Spy. Kádár tried to convince Rajk to admit to the charges. 


\section{THE PRAGUE SPRING}

During the events of the Prague Spring Kádár, already an experienced politician, was an active external participant. He had been in power for thirteen years, and had experience in crises much like that that took place in Czechoslovakia. It has been well documented that Kádár supported the experiment of the establishment of socialism with a human face, and also had excellent relations with Alexander Dubček. During this period, János Kádár and Gustáv Husák did not have direct contact.

Dubček was appointed at the beginning of January 1968. The party leadership of the German Democratic Republic, Poland and Bulgaria disapproved of it, and Moscow had taken note of the change; only Kádár received it with joy. Dubček appreciated Kádár, and Kádár also hoped that the reformist Czechoslovakia would be an ally to Hungary. During the spring of 1968 , the two politicians met seven times, including six times of bilateral discussion. Hungary, up to the bilateral meeting in July $13^{\text {th }}$, steadily defended the current leadership of the Czechoslovak Communist Party (CZSCP), which in the early months of the Prague Spring, saw the CZSCP looking for problems and mistakes committed in the former Novotny era. ${ }^{4}$ For Kádár, it was apparent that the Hungarian Socialist Workers' Party (HSWP) could not oppose for long the other communist parties. Therefore, Hungary officially switched positions and now opposed the reforms taking place across its border. According to János Kádár, Hungary would have missed participation in the military invasion, and had lost the opportunity to influence events, which would make the steps of the Soviet Union even more unpredictable.

Despite the criticism formulated by Kádár against the policy of CZSCP in June, which surprised even Dubček, in a meeting in Yalta between August $12^{\text {th }}$ and $15^{\text {th }}$, he repeatedly criticized the method of resolving the Czechoslovak problem. Kádár told Brezhnev, Kosygin and Podgorny his criticism about the Soviet tactic, and strongly advocated a political solution. As we all know, at that time the plan of the military occupation of Czechoslovakia was already under way. According to Kádár, the Communist Party of the Soviet Union had to take a stand for the new solutions and the equality of fraternal parties had to be respected. A military solution should only be applied as a last resort.

After the military invasion, Dubček and Kádár lost connection, and control passed into the hands of Brezhnev. Kádár intervened for the last time at the Soviet-East German-Polish-Hungarian-Bulgarian meeting of $17^{\text {th }}$ September,

4 Antonín Novotný (1904-1974) was, between September 1953 and January 1968, the Secretary-General of the Czechoslovak Communist Party. 
when he called for the earliest withdrawal of Warsaw Pact troops. The preparation of the Czechoslovak-Soviet military agreement was even consulted with him, but Czechoslovakia had become, ultimately, a Soviet affair (Vida, 2001) despite the domestic success of the Prague Spring, and Kádár's earlier defence of the reforms in Czechoslovakia by Alexander Dubček.

\section{NORMALISATION AND GOULASH COMMUNISM}

The two politicians generally resembled each other in how they governed their countries; more precisely, what kind of real socialism developed there. The difference was clearly also visible to all of their contemporaries.

Between 1969 and 1989, János Kádár and Gustáv Husák held a very similar position in their countries, which granted them basically the same power. János Kádár was the head of Hungary from November 1956. His position was the First Secretary in the Central Committee of the HSWP. From the same year he was also a member of the Presidential Council. From March 1985 until May 1988 he was the Secretary General of the Central Committee. Gustáv Husák, from April to December 1968, held the position of the Czechoslovak government's deputy prime minister, between 1969 and 1971 the position of the first secretary of the CZSCP and, from 1987 the position of Secretary-General. Between 1975 and 1989, Husák was the President of the Czechoslovak Socialist Republic.

The normalization and return to the orthodox form of socialism in Czechoslovakia is associated with the name of Husák. It should be clarified that this was an extremely controversial era. On the one hand, society had undergone huge moral crises; on the other hand, within the Eastern bloc, Czechoslovakia went through the most stable development (see Graph 1). Despite the fact that looking back on the events the era used to be evaluated generally negatively, the population did not show any resistance (Mervart, 2013, pp. 649-650). ${ }^{5}$

In 1969 Czechoslovakia reached a significant and unique new era. A general description of the period is "normalization" but another commonly used name is derived from the chief conductor - "the Husák era". The literature knows other names such as "a real normalization of socialism", "developed socialism", simply the regime "which is here" or even longer terms such as "export goods taken by the tanks of friendly armies" (Mervart, 2013, p. 649). Gustáv Husák biographer, Viliam Plevza, writes that "the hallmark of foreign policy propaganda in the name of Husák was, at that time, identified by stiffening and conservatism" (Plevza, 1991, p. 143). It was a name with a greater emotional charge that was, according to the political scientist Miroslav Kusý "a strait-laced neoStalinist

5 Charta 77 supported only a very narrow circle of intellectuals. 
system" (Kusý, 2002, p. 211).

János Kádár was also a dominant personality in Hungarian history who gave his name to a historical period as well. Besides Kádárism or the Kádár regime, there are other terms portraying the period more expressively. The best-known attribute is probably goulash communism. The term refers to the welfare system created by Kádár, which, however, as we know was sustainable only at the cost of enormous debt. Other names about this era, marked by this politician, were "consumer socialism", "the Kádár-era's deformation of real socialism" and "the caring socialist welfare state" (Valuch, 2005, p. 361, 364). Iván Berend also adds the meaningful phrase "refrigerator socialism" (Berend, 1999, p. 259). It should also be mentioned that the phrase "soft dictatorship" is used in several places as well. Finally, it is worth noting that the people who lived at that time also lived in way typical for the age. It evolved into a contemporary indicator, namely the "homo kádáricus" (2003, Huszár, p. 258). ${ }^{6}$

\section{A REFORMIST AND AN ANTIREFORMIST}

The two politicians can be assessed from several points of view. We are doing this on the basis of their relations to economic reforms. It was already known that, within the socialist bloc, in economic reforms Hungary was at the forefront; however, Czechoslovakia rejected almost all the changes. János Kornai sums up the the two countries' economic reforms in the following timetable:

Table 1 shows that the launch of real economic reforms in Hungary came at the time when Czechoslovakia was only in the Husákian normalization period.

The Hungarian economic policy's perhaps most characteristic feature, which, incidentally, has remained in Hungarian economic management until now, is the "stop - go" policy. This phrase means that from time to time within an economic system preferences are significantly transformed, which then lead to serious economic policy changes. Behind the cyclical policy lay more reasons, which have a large and growing literature. The phenomenon appeared in daily policy, and from the ' 80 s began to deal with large segments of society. The literature (Ungvárszki, 1989) sets out the following breakpoints: 1953, 1958-59, 196667, 1971-72, 1979 and 1985. The changes of direction are linked to a struggle between the two "opposite poles", renewal trends and doctrinal direction. The first numbers indicate the waves of investment into heavy industry and the second numbers indicate the period of reform efforts, when agriculture and the

6 The term Homo czechoslovakus occurred in Slovak literature, but refers to linguistically degenerate people confusing the Slovak and Czech language, such as Karol Bacílek or Gustáv Husák (Renner \& Samson, 1993, p 34). 
production of consumer goods came to the fore. The periods of 1948-53, 1959-65 and 1972-78 characterized the first tendency, during the middle periods we have witnessed a strengthening of the forces of reform. As is written by Szamuelly and Csaba (1997, p. 38) "... the question of economic reforms was almost always on the agenda during the three decades of the Kádár regime."

Table 1: Schedule of reform measures

\begin{tabular}{|l|c|c|}
\hline & Hungary & Czechoslovakia \\
\hline $\begin{array}{l}\text { The abolition of the compulsory delivery sys- } \\
\text { tem in agriculture }\end{array}$ & 1956 & 1960 \\
\hline $\begin{array}{l}\text { The abolition of a compulsory planned econo- } \\
\text { my }\end{array}$ & 1968 & 1990 \\
\hline Termination of the main indicators & 1968 & 1990 \\
\hline The beginning of the abolition of price control & 1968 & 1991 \\
\hline The introduction of a single currency & 1981 & 1991 \\
\hline Membership in the IMF and the World Bank & 1982 & 1990 \\
\hline $\begin{array}{l}\text { Significant facilitation in the field of entrepre- } \\
\text { neurship and private ventures }\end{array}$ & 1982 & 1991 \\
\hline The adoption of the Bankruptcy Act & 1986 & 1991,1992 \\
\hline The introduction of a two-tier banking system & 1987 & 1990 \\
\hline The introduction of personal income tax & 1988 & 1993 \\
\hline The introduction of Value Added Tax & 1988 & 1991 \\
\hline $\begin{array}{l}\text { Adoption of a law governing the registration of } \\
\text { companies }\end{array}$ & 1989 & 1991 \\
\hline Trade liberalization & 1989 & 1991 \\
\hline The introduction of unemployment aid & 1989 & 1991 \\
\hline
\end{tabular}

Source: Kornai 1998, 98

Among the above-mentioned reform waves, the most significant is the new economic mechanism started in 1968. After this year, the policy did not return to Stalinism, although the reforms stalled several times. The changes can be summarized briefly as follows: the annual five-year plans for companies was finished; corporate autonomy increased; the supervisory body could not regulate companies anymore; the central allocation of production factors were replaced by their market purchase; to the small private property were recognized equal rights as to state and cooperative forms of ownership; companies could made 
decisions relating to routine production alone; companies could realize their developments from their profit fund or bank loans; in the National Planning Office some functions and departments were reduced or eliminated; the plan and the market became not mutually exclusive, but rather complementary categories; the price of about $25 \%$ of consumer goods was liberalized; the general government deficit began to increase; for foreign trade, the dollar and rouble currencies were introduced; tension on the labour market was eased (Honvári, 2005, p. 722-732).

The road leading to the Prague Spring started with economic reforms. The cause was problems in implementing the Third Five-Year Plan (1961-1965) (Šik, 1990, pp. 94-95). The heart of the reform, Ota Šik, was a self-professed leftistminded man who did not want to go back to capitalism, who tried to eliminate or reduce the internal contradictions of the socialist economy. The proposed changes can be summarized as follows: offer room for a free market; introduce price as a control in demand and supply; increase the financial interest of companies; company income could depend on sales. Investment would remain centralized, as well as the labour market. As for price, three categories were distinguished: the defined, the limited and the free price. The price categories were introduced on January 1th 1967. The concept was opposed by the leaders of CZSCP from the beginning; it was supported almost only by reform economists around Ota Šik under the auspices of the Czechoslovak Academy of Sciences Institute of Economics (Průcha, 2009, pp. 382-389).

Graph 1: GDP growth of Hungary and Czechoslovakia between 1950 and 1982

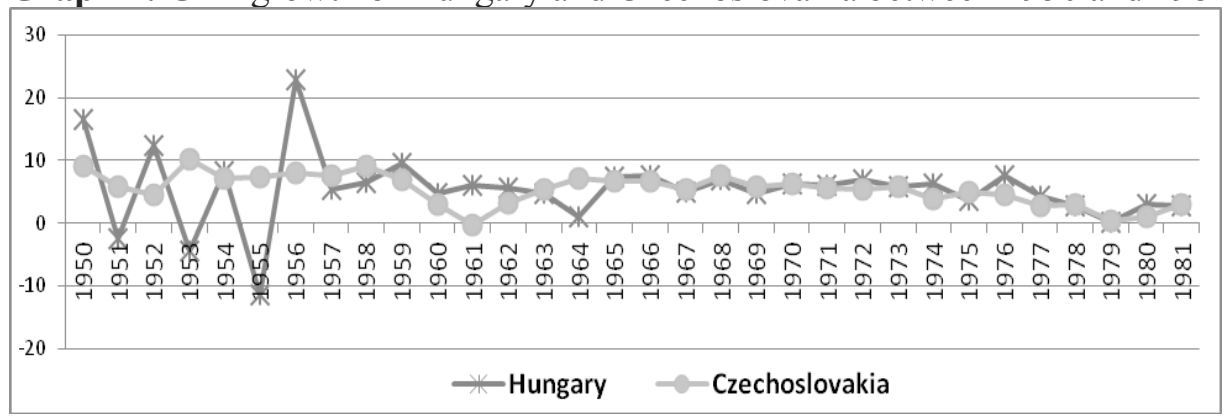

Source: Hungary: Magyarország népessége és gazdasága (1996), p. 96; Czechoslovakia: Historická statistická ročenka ČSSR (1985), p. 85

Now we already know that while the reforms in Hungary, thanks to János Kádár, survived and evolved further, the reforms in Czechoslovakia, thanks to Gustáv Husák personally, after 1969 practically ceased to exist. Any change was branded as revisionism. Many economists were dismissed; many of them, 
including Šik, had to leave the country. The conditions began to resemble the dogmatic era of the '50s. In 1970 the government announced its plan to return to direct control and administrative-directive methods. The idea of reform took place again only after the appearance of Perestroika. Gustáv Husák realized the need for change only in 1987. In this year the document entitled, Principles of Economic Transformation Mechanism of the Czechoslovak Socialist Republic was published which, however, was not able to follow the event (Průcha, 2009, pp. 697-706).

According to Nyers ${ }^{7}$, the reform policy in Hungary did not begin with János Kádár entering the stage of policy, but with Imre Nagy. At the time of the declaration of the "new phase" during the spring of 1953, Kádár was in prison (Nyers, 2001, p. 133). János Kádár, in some ways, got in their way. In fact, however, the reforms of the ' $60 \mathrm{~s}$ and ' 70 s would not have taken place without the approval of Kádár. The root of the cause of the reforms used is formulated as follows: the Hungarian political elite tried to pacify the gun-resistant society in 1956 with various concessions which, among others, included greater financial well-being; the party's leadership noticed that the socialism realized in the Soviet Union was full of serious economic problems, and Hungary needed modifying. The changes, of course, were caused by other reasons also, such as the structural problems of the Hungarian economy, external economic factors (oil crisis) or the dried up support of the Soviet Union. The Hungarian economic reforms were nevertheless unique in Eastern Europe. Something similar happened only in Yugoslavia, in a country which went its own way from 1947 and Czechoslovakia should have followed if the Prague Spring had not stopped it. Nyers, the leading person of the new economic mechanism, considers János Kádár as a supporter of reform, even if he stopped in time (Nyers, 2001, p. 135).

According to Tibor Huszár, the most comprehensive biography writer of Kádár, the role of first secretary Nyers, contrary to opinion, was slightly different. While Nyers claims that had Kádár had a small hand in preparation, during the decision-making process he played a great role. Huszár said that Kádár's role was controversial. In the preparation involving technical issues he played a minor role. In fact, however, the approval was a political act, which also needed courage. After the dismissal of Khrushchev in 1964 there was not a suitable

7 Rezső Nyers (1923), one of the elaborators of the New Economic Mechanism. Between 1957 and 1989, a member of the Central Committee of the HSWP. Among others positions he was Minister of Finance (1960-1962) and Director of the Economic Institution of the Hungarian Academy of Science.

8 The period between 1953 and 1955. Mátyás Rákosi was relieved of his post of prime minister. The political terror ceased as well as the unilateral development of industry at the expense of agriculture and consumer goods. 
climate for reforms, but the accumulation of problems in 1965 forced Kádár to move on. The reforms would have eradicated the socialist character of the economy, but Kádár did not want this (Huszár, 2003, pp. 199-200, 288-292).

However, the restoration of 1973-74 was caused by external reasons. Kádár, during his visit to Moscow in 1972, received serious criticism from Brezhnev.

Table 2: Some indicators of development in Hungary and Czechoslovakia

\begin{tabular}{|l|c|c|c|c|c|c|c|c|}
\hline & & 1960 & 1965 & 1970 & 1975 & 1980 & 1985 & 1989 \\
\hline $\begin{array}{l}\text { Flat constr./1000 } \\
\text { inhab. }\end{array}$ & $\mathrm{H}$ & 171,6 & 185,7 & 128,6 & 105,4 & 120,2 & 146,2 & 202,4 \\
\hline & $\mathrm{CZ}$ & 185,6 & 182,7 & 119,0 & 102,7 & 118,6 & 148,3 & 176,6 \\
\hline $\begin{array}{l}\text { No. of univ. stud. } \\
\text { /1000 inhab. }\end{array}$ & $\mathrm{H}$ & 2,59 & 4,81 & 5,16 & 6,01 & 6,02 & 5,96 & 6,88 \\
\hline & $\mathrm{CZ}$ & 4,78 & 6,46 & 7,64 & 8,03 & 6,97 & 8,84 & 8,82 \\
\hline $\begin{array}{l}\text { No. of publ. book } \\
\text { title/10000 inhab. }\end{array}$ & $\mathrm{H}$ & 2,98 & 3,90 & 4,64 & 7,36 & 7,70 & 7,56 & 7,29 \\
\hline & $\mathrm{CZ}$ & 5,03 & 4,58 & 4,67 & 4,69 & 4,79 & 4,49 & 4,39 \\
\hline $\begin{array}{l}\text { Consummation of } \\
\text { milk, kg(1)/inhab. }\end{array}$ & $\mathrm{H}$ & 114,0 & 97,1 & 109,6 & 126,6 & 166,2 & 183,2 & 186,9 \\
\hline & $\mathrm{CZ}$ & 108,6 & 106,5 & 119,2 & 117,5 & 113,2 & 111,1 & 99,6 \\
\hline $\begin{array}{l}\text { Bathroom [\%/house- } \\
\text { hold] }\end{array}$ & $\mathrm{H}$ & 17,5 & - & 31,9 & - & 59,7 & - & - \\
\hline & $\mathrm{CZ}$ & 33,3 & - & 58,6 & - & 81,3 & - & - \\
\hline $\begin{array}{l}\text { Water supply [\%/hou- } \\
\text { sehold] }\end{array}$ & $\mathrm{H}$ & 22,5 & - & 35,9 & - & 64 & - & - \\
\hline & $\mathrm{CZ}$ & 49,1 & - & 75,3 & - & 89,5 & - & - \\
\hline $\begin{array}{l}\text { Gas supply [\%/house- } \\
\text { hold] }\end{array}$ & $\mathrm{H}$ & 13,5 & - & 50,7 & - & 75,7 & - & - \\
\hline & $\mathrm{CZ}$ & 19,7 & - & 30,5 & - & 40,2 & - & - \\
\hline $\begin{array}{l}\text { Refrigerator [\%/hou- } \\
\text { sehold] }\end{array}$ & $\mathrm{H}$ & 1 & - & 35 & - & 87 & - & - \\
\hline & $\mathrm{CZ}$ & 13,1 & - & 61,1 & - & 87,8 & - & - \\
\hline $\begin{array}{l}\text { Washing machine [\%/ } \\
\text { household] }\end{array}$ & $\mathrm{H}$ & 19 & - & 70 & - & 91 & - & - \\
\hline & $\mathrm{CZ}$ & 54,6 & - & 68,2 & - & 83,6 & - & - \\
\hline TV set [\%/household] & $\mathrm{H}$ & 5 & - & 66 & - & 99 & - & - \\
\hline & $\mathrm{CZ}$ & 23,6 & - & 74,6 & - & 88,6 & - & - \\
\hline Car [\%/household] & $\mathrm{H}$ & 0 & - & 6 & - & 26 & - & - \\
\hline & - & 17,4 & - & 38,3 & - & - \\
\hline
\end{tabular}




\begin{tabular}{|l|c|c|c|c|c|c|c|c|}
\hline Retail prices [\%] & $\mathrm{H}$ & - & - & 100 & 156 & 245 & 364 & - \\
\hline & $\mathrm{CZ}$ & - & - & 100 & 130 & 156 & 182 & - \\
\hline Retail turnover [\%] & $\mathrm{H}$ & - & - & 100 & 135 & 153 & 164 & - \\
\hline & $\mathrm{CZ}$ & - & - & 100 & 130 & 140 & 146 & - \\
\hline
\end{tabular}

Sources: 1-7: Magyarország népessége és gazdasága, p. 104-105; 4: 1985: Statistická ročenka České a slovenské federatívni republiky '91 1991, p. 320; 8-12: Romsics, 2005, p. 481; 13-14: Průcha \& Urban, 1989, p. 235, p. 238; 5-10: in case of Czechoslovakia year 1961

The Soviet general secretary's opinions about in Hungary concerned the pettybourgeois views, in agriculture capitalist relations were restored, the party did not care about social justice and political vigilance had subsided (Romsics, 2005, p. 451). Kádár was forced to compromise. After the death of Leonid Brezhnev in 1982, the first man in the Soviet Union became Yuri Andropov. Andropov was ambassador in Budapest in 1956, so he was familiar with Kádár. When Kádár visited him in 1983, he agreed with the Hungarian reforms (Romsics, 2005, p. 455). Kádár, then, when it was possible, continued to restructure the economy.

The Czechoslovak economic reforms began also before Gustáv Husák gained the leadership. However, while the consolidation of Kádár meant a search for new roads, Husák consolidated the return to the old system, the stop of reforms, and the silence or emigration of reformers. In fact, the Czechoslovak economy was in better shape than that of Hungary and did not need radical reforms. By and by, Czechoslovakia had fallen slowly behind the West, like the other countries in the socialist bloc; however, it remained one of the most developed states. The debt was approximately one third that of the Hungarian (Janos 2003, 304), economic growth was much more even (see Graph 1), and welfare was also slightly higher. We know now, however, that the Czechoslovak Statistical Office published falsified data (Sixta \& Vltavská \& Fischer, 2013).

It should also be recognized when Gustáv Husák within his position of party secretary-general did a tremendous job. He worked 14-16 hours per day, seven days a week. His main intention was to lead the country out of the political and economic crisis. This was a difficult task because there was also a crisis of values. On the one hand it was due to the Soviet occupation, on the other because of the weakness of its own leaders or their betrayal. This included the betrayal of Husák himself, who said publicly he stood up for the principles of Dubček. Then, when he was elected leader of the Communist Party, the public could see every day how in the republic he applied once again the most disgusting communist methods.

Husák at first stabilized the regime. He realized that in the beginning he must 
achieve the financial security of the population. A price reduction at that moment could not be executed, so he asked for help from the Soviet Union. Over the next decade, private consumption increased, but they also re-introduced censorship (Pernes, 2003, pp. 291-292).

\section{APPRAISAL BY HISTORIANS}

The lives of these two politicians have already been paralleled by historians. On the occasion of the $100^{\text {th }}$ anniversary of the birth of Gustáv Husák, a thick biography was published in which Vilém Prezan evaluates his balance of life right up to Kádár: "Husák, so brave a thing was he, so resourceful and ruthless; when he got to the top of the pyramid of power, he never used his power and influence for the benefit of the country and its future. When compared with the attitude of János Kádár, who in 1956 proved the Soviets a similar service as Husák did from August 1968; however, after a few years, Hungary achieved substantial relief and began the era of liberalization" (Prezan, 2013, p. 37).

Kádár has a better reputation with other Slovak historians. Ivo Samson gives him the epithet "tactic" (Renner \& Samson, 1993, 57), which is in consideration of his actions and carefulness with dogmatists, and the action program of the CZSCP among the other communist party leaders being acceptable only to him (Renner \& Samson, 1993, p. 75).

Regarding the year 1968 one question still arises: why did Kádár, who partly succeeded in achieving socialism with a human face and who sympathized with Alexander Dubcek, participate in the military intervention against Czechoslovakia? The above mentioned biography of Husák gives the answer: in Hungary, in spite of the country introducing some reforms, in the international political scene it continued to be the backbone of the Soviet Union (Mitrovits, 2013, pp. 936-937).

Miklós Mitrovits stresses that given the fact that Husák was in Gottwald's prison for seven years, one would expect that the process of deStalinazation would resume and he would also continue the progressive social and economic reforms. The opposite became truth. "Husák legitimately not only did not follow the example of the Hungarian political practice of the years 1968-69, but even the years 1956-57; Czechoslovakia did not confront Stalinism, therefore it was not possible to expand the horizon or policies of the Communist Party in the manner of Kádár's “alliance policy” (Mitrovits, 2013, p. 947).

After the Prague Spring, a Slovak historian evaluated Husák's role: "While the absolute majority of citizens condemned the occupation, and even most members of his party and Husák verbally did the same, he took on the role of 
chief of normalization. He and his new allies - the Bilakian crowd and Lenártian flunkies - from the early ' 70 s tried to clear the people's memory and seduce them into believing that the occupation was international assistance. Objectively, however, it is clear that to Bilaks, Jakešes and Indra's did not allow him to do political process. The project of exemplary condemnation of the 40,000 counterrevolutionaries by the worker-revolutionary government (part should hang, part be sent to Siberia and the others go to prison for a year), thankfully, he did not realize. They did not allow the creation of widows, but against the psychological murder of disagreement and the occupation and the imperialist policy of the USSR he did nothing. He did not move a finger for the people, who rehabilitated him, and after returning from prison helped him to return to political life, when they were excluded from the party and routed out to the periphery of life. In contrast, he left Viliam Široký, Karel Bacílek and Antonín Novotný, who sent him for nine years to prison, in the communist party" (Plevza, 1991, p. 9).

During the '70s, the relationship between Kádár and Husák deteriorated. Such a development of events was due to criticism of the Hungarian economic policy of the party and allegations of Hungarian nationalism. In the background of these criticisms stood Vasil' Bilak, but Husák also did not adopt all of Kádár's proposals. Czechoslovak-Hungarian relations nevertheless developed in the spirit of proletarian internationalism. In the ' $80 \mathrm{~s}$, meetings between the two communist leaders reduced to one-day visits (Mitrovits, 2013, pp. 948-953).

\section{CONCLUSION}

In the economic policies of Gustáv Husák and János Kádár there are some similar traits. They both were given notice that their own power, as well as the power of the communist party, could only be maintained if they made concessions for society. Given the fact that both of them were planted in their chairs by Moscow, they could not make any political concessions. The only economic concessions Husák and Kádár had to make concerned trying to raise the standard of living. As for the historical reasons why the former Czechoslovakia was a developed country, so Kádár was forced to make major concessions. However, while all along Husák was ready to make only welfare measures, Kádár was willing to change the political course as well.

The thaw had already begun in Hungary in the mid '60s. It is no coincidence that Kádár sympathized with the establishment of socialism with the human face place and with Dubcek in person. When Gustáv Husák came to power, János Kádár had already been developing a similar kind of socialism for five years.

Despite the fact that Husák came to power in same way as Kádár, he represented 
a completely different policy. While Kádár's policy, with some interruptions, step by step led to the breakdown of socialism, Husákian Czechoslovakia has always remained a post-Stalinist country.

\section{REFERENCES}

Berend T. I. 1999. Terelöúton. Vince Kiadó, Budapest Historická statistická ročenka ČSSR. 1985). SNTL, Alfa, Praha

HonváRI J. 2005. Magyarország gazdaságtörténete Trianontól a rendszerváltásig. Aula, Budapest

Huszár T. 2001. Kádár. Vol 1. Szabad Tér Kiadó, Kossuth Kiadó, Szekszárd Huszár T. 2003. Kádár. Vol 2. Szabad Tér Kiadó, Kossuth Kiadó, Szekszárd János, A. C. 2003. Haladás, hanyatlás, hegemónia Kelet-Közép-Európában. Helikon, Szekszárd

KornaI, J. 1998. Od gulášového komunizmu k trhovej ekonomike. Kalligram, Bratislava

Magyarország népessége és gazdasága. Múlt és jelen. 1996) Budapest, KSH

KusÝ, M. 2002. A magyarkérdés Szlovákiában. Kalligram, Pozsony

MERVART, J. 2015. „Reálný socializmus“ rané normalizace , kontinuita ši diskontinuita. Michálek, S. \& Londák, M. et al. Gustáv Husák, moc politiky, politik moci. Veda, Bratislava, pp. 649-660

Mitrovits M. 2013. Husák a Kádár. Československo- mad’arské vzt’ahy v rokoch 1968-1989. Michálek, S. \& Londák, M. et al. Gustáv Husák, moc politiky, politik moci. Veda, Bratislava, pp. 935-953

Nyers R. 2001. Kádár János és a reformok. Rácz Árpád red. Ki volt Kádár? Harag és részrehajlás nélkül. Rubicon-Aquila, Budapest, pp. 133-135

Pernes, J. 2003. Takoví nám vládli. Brána, Praha

Plevza, V. 1991. Vzostupy a pády. Gustáv Husák prehovoril. Bratislava, Tatrapress

PreZAn, V. 2013. Iluze a skotečnost. Michálech, S. \& Londák, M. et al. Gustáv Husák, moc politiky, politik moci. Veda, Bratislava, pp. 26-39

Průcha, V. \& URBAN, L. et al. 1989. Hospodársky vývoj evropských zemí RVHP. Svoboda, Praha

Průcha, V. et al. 2009. Hospodářské a sociální dějiny Československa. 2. díl obdobi 1945-1992. Doplněk, Brno

RenNer, H. \& SAMson, I. 1993. Dejiny Československa od roku 1945. Bratislava, Slovak Academic Press

Romsics I. 2005. Magyarország története a XX. században. Osiris, Budapest

Sikora, S. 2013 Gustáv Husák a režimy Československa. Michálech, S. \& 
LoNDÁK, M. et al. Gustáv Husák, moc politiky, politik moci. Veda, Bratislava, pp. 40-66

Sixta, J. \& Vltavská, K. \& Fischer, J. 2013. The Development of Gross Domestic Product in the Czech Republic and Slovakia between 1970 and 1989. Ekonomický časopis, vol. 61. no. 6, pp. 549-562

Statistická ročenka České a slovenské federatívni republiky '91. 1991. Federální statistický úřad, Český statistický úřad, Slovenský štatistický úrad, SEVT, Praha

Szamuely L. \& Csaba L. 1998. Rendszerváltás a közgazdaságban \& közgazdaságtan a rendszerváltásban. Közgazdasági Szemle Alapítvány, Budapest

ŠıK, O. 1990. Jarni probouzení. Iluze a skutočnost'. Mladá Fronta, Praha

ŠUtAJ, Š. 2013. Husák a slovenskí Mad'ari v rokoch 1945-1949. Michálech, S. \& LondÁk, M. et al. Gustáv Husák, moc politiky, politik moci. Veda, Bratislava, pp. 282-311

UngvárszKi Á. 1989. GazdaságPolitikai ciklusok Magyarországon (19481988). Gazdasági és Jogi Könyvkiadó, Budapest

Valuch T. 2005. A ,gulyáskommunizmus”. Romsics Ignác red. Mítoszok, legendák tévhitek a 20. századi magyar történelemböl. Osiris, Budapest

VIDA I. 2001. Kádár és Dubcek. Rácz Árpád red. Ki volt Kádár? Harag és részrehajlás nélkül. Rubicon-Aquila, Budapest, pp. 95-102 